\title{
Suppression of islet homeostasis protein thwarts diabetes mellitus progression
}

\author{
Seh-Hoon Oh${ }^{1}$, Marda L Jorgensen ${ }^{1}$, Clive H Wasserfall ${ }^{2}$, Altin Gjymishka ${ }^{1}$ and Bryon E Petersen ${ }^{1}$
}

During progression to type 1 diabetes, insulin-producing $\beta$-cells are lost through an autoimmune attack resulting in unrestrained glucagon expression and secretion, activation of glycogenolysis, and escalating hyperglycemia. We recently identified a protein, designated islet homeostasis protein (IHoP), which specifically co-localizes within glucagon-positive $a$-cells and is overexpressed in the islets of both post-onset non-obese diabetic (NOD) mice and type 1 diabetes patients. Here we report that in the $a \mathrm{TC} 1.9$ mouse $a$-cell line, IHoP was released in response to high-glucose challenge and was found to regulate secretion of glucagon. We also show that in NOD mice with diabetes, major histocompatibility complex class II was upregulated in islets. In addition hyperglycemia was modulated in NOD mice via suppression of IHoP utilizing small interfering RNA (IHoP-siRNA) constructs/approaches. Suppression of IHoP in the pre-diabetes setting maintained normoglycemia, glyconeolysis, and fostered $\beta$-cell restoration in NOD mice 35 weeks post treatment. Furthermore, we performed adoptive transfer experiments using splenocytes from IHoP-siRNA-treated NOD/ShiLtJ mice, which thwarted the development of hyperglycemia and the extent of insulitis seen in recipient mice. Last, IHoP can be detected in the serum of human type 1 diabetes patients and could potentially serve as an early novel biomarker for type 1 diabetes in patients.

Laboratory Investigation (2017) 97, 577-590; doi:10.1038/labinvest.2017.15; published online 20 February 2017

Glucagon is a crucial regulatory hormone that counteracts insulin activity by promoting glucose mobilization from the liver through glycogenolysis and gluconeogenesis. Low blood glucose levels trigger the release of glucagon from pancreatic islet $\alpha$-cells, which in turn opposes the release of insulin from islet $\beta$-cells to provide systemic glucose balance. ${ }^{1-3}$ This response is progressively diminished in type 1 diabetes resulting in uncontrolled hyperglycemia and associated changes in islet constitution. ${ }^{4,5}$ Pathological analysis of preonset type 1 diabetes pancreatic islets showed widespread glucagon overexpression throughout the islet structure. ${ }^{6}$ Postonset type 1 diabetes pancreatic islets revealed a loss of $\beta$-cells with insulin-deficient islets that were typically shrunken in size, but otherwise contained a normal complement of all other islet cell types. ${ }^{6-8}$

In diabetes, it is the unrestrained secretion of glucagon taking action on the liver that leads to undesirable metabolic consequences. Glucagon inhibitors may provide a mechanism to demonstrate the fundamental role of glucagon in the metabolic phenotype of type 1 diabetes. ${ }^{9}$ Furthermore, experiments using an adenoviral approach to suppress glucagon in type 1 diabetes mice resulted in normoglycemia without insulin involvement. ${ }^{10}$ As a key counter regulatory hormone responsible for opposing the glucose-lowering effect of insulin, glucagon represents an attractive therapeutic target for the treatment of type 1 diabetes. Recently, we described a protein, identified as islet homeostasis protein (IHoP), which was shown to effect glucagon synthesis and secretion within the pancreatic $\alpha$-cell. In addition, the role of IHoP appears to involve the regulation of other pancreatic hormones. ${ }^{11}$

To further understand the role IHoP has in hyperglycemic progression, we designed a series of experiments to define the function of IHoP both in vitro and in vivo and to identify other components involved in this pathway. We previously reported that $\mathrm{IHoP}$ was overexpressed in the pre-onset stage of type 1 diabetes and its murine equivalent ${ }^{11}$ and now postulate that if IHoP could be suppressed to normal levels then balance between glucagon and insulin could be restored. To test this hypothesis, we created a siRNA construct to knock down IHoP expression in both pre- and post-onset non-obese diabetic (NOD) mice. The results indicate that IHoP can regulate $\alpha$-cell function, thereby mediating

${ }^{1}$ Department of Pediatrics, College of Medicine, University of Florida, Gainesville, FL, USA and ${ }^{2}$ Department of Pathology, Diabetes Institute, Colleges of Medicine, University of Florida, Gainesville, FL, USA

Correspondence: Dr S-H Oh, PhD, Department of Pediatrics, College of Medicine, University of Florida, PO Box 100296, Gainesville, FL 32610, USA.

E-mail: sehoon@ufl.edu

Received 10 September 2016; revised 29 December 2016; accepted 1 January 2017 


\begin{tabular}{|c|c|c|}
\hline Gene name & Primer sequences & Product size \\
\hline \multirow[t]{2}{*}{ Insulin } & Forward 5'-TAGTGACCAGCTATAATCAGAG-3' & $289 \mathrm{bp}$ \\
\hline & Reverse 5'-ACGCCAAGGTCTGAAGGTCC-3' & \\
\hline \multirow[t]{2}{*}{ Glucagon } & Forward 5'-AACAACATTGCCAAACGTCA-3' & $330 \mathrm{bp}$ \\
\hline & Reverse 5'-TCCGCAGAGATGTTGTGAAG-3' & \\
\hline \multirow[t]{2}{*}{ Full-length $\mathrm{HO}_{\mathrm{O}} \mathrm{P}$} & Forward 5'-GTAGATCTGAAGGACTGGGG-3' & 1975 bp \\
\hline & Reverse 5'-GGTAGACTTTCAAAGAATAA-3' & \\
\hline \multirow[t]{2}{*}{ IHoP internal } & Forward 5'-GTAGATCTGAAGGACTGGGGT-3' & $586 \mathrm{bp}$ \\
\hline & Reverse 5'-ACAAAGAACTATGCCATCGCC-3' & \\
\hline \multirow[t]{2}{*}{ IHOP high specificity region } & Forward 5'-AGTTGATACCGATGGCAAA-3' & $276 \mathrm{bp}$ \\
\hline & Reverse 5'-ACGCTGGACTGCTCAGAG-3' & \\
\hline \multirow[t]{2}{*}{ L-Plastin } & Forward 5'-GGCCCCTAATTCTGCTGCGGG-3' & 2476 bp \\
\hline & Reverse 5'-GGTAGACTTTCAAAGAATAA-3' & \\
\hline \multirow[t]{2}{*}{ MHC Class II } & Forward 5'-CCTGGAGGAGCCGGTTCT-3' & $341 \mathrm{bp}$ \\
\hline & Reverse 5'-GATCGCAGGCCTTGAATGAT-3' & \\
\hline \multirow[t]{2}{*}{$\beta$-actin } & Forward 5'-TCCTATGTGGGTGACGAGGC-3', & $245 \mathrm{bp}$ \\
\hline & Reverse 5'-TACATGGCTGGGGTGTTGAA-3' & \\
\hline \multirow[t]{2}{*}{ GAPDH } & Forward 5'-ATCACTGCCACTCAGAAGAC-3', & $586 \mathrm{bp}$ \\
\hline & Reverse 5'-TGAGGGAGATGCTCAGTGTT-3' & \\
\hline
\end{tabular}

homeostasis and islet regeneration. We also report that in the pre-onset NOD mouse, if IHoP is suppressed to normal levels, blood glucose levels are also normalized. In addition, all type 1 diabetes patients we tested were positive for IHoP, whereas nondiabetic controls were found to be negative. This suggests a role for IHoP as a new biomarker, potentially capable of early detection of pre-diabetic changes within the islet.

\section{MATERIALS AND METHODS}

\section{Cell Lines and Proliferation Assay}

Mouse-derived glucagon-synthesizing $\alpha \mathrm{TC} 1.9$ and insulinproducing $\beta$ TC6 cells, gifts from Dr Michael S Lan (LSUHSC and Research Institute for Children, Children's Hospital, New Orleans, LA, USA), were maintained using previously reported methods. ${ }^{12}$ The $\alpha$ TC1.9 cells were transfected with IHoP-siRNA using Lipofectamine 2000 (Invitrogen, Carlsbad, CA, USA). IHoP-siRNA- $\alpha$ TC1.9 cells were cultured with the addition of zeocin (Invitrogen). To determine the effect IHoP had on cell proliferation, CellTiter 96 Aqueous One Solution Cell Proliferation assay was performed following the manufacturer's instructions (Promega, Madison, WI, USA). Briefly, $\alpha \mathrm{TC} 1.9$ cells were plated $\left(1 \times 10^{4}\right.$ cells/well in $\alpha \mathrm{TC} 1.9$ cell medium). After $24 \mathrm{~h}$, the media was replaced with 10\% FBSsupplemented high-glucose DMEM (positive control), serumfree high-glucose DMEM medium containing 0.5\% bovine serum albumin (BSA; negative control), or $0.5 \%$ BSA medium with IHoP $(1 \mu \mathrm{g} / \mathrm{ml})$. The cells were cultured in designated media for 24,48 , and $72 \mathrm{~h}$ before being analyzed by spectrophotometry (490 $\mathrm{nm})$.

\section{Diabetic Mouse Model}

NOD/ShiLtJ mouse strain is a well-studied polygenic model for type 1 diabetes. Diabetes in NOD/ShiLtJ mice is characterized by insulitis, a leukocytic infiltration of the pancreatic islets. Marked decreases in pancreatic insulin production occur in females at about 12 weeks of age. Consequently, plasma glucose levels spontaneously increase to greater than $250 \mathrm{mg} / \mathrm{dl}$. IDDM symptoms occur at an incidence of $90-100 \%$ by 30 weeks of age.

\section{Detection of IHoP mRNA}

Total RNA was extracted using RNase Bee (TEL-TEST, Friendswood, TX, USA) according to the manufacture's protocol. cDNA was prepared by reverse transcription, using $2 \mu \mathrm{g}$ of DNA-free RNA as template for the SuperScript III First-Strand Synthesis System kit (Invitrogen). Type 1 diabetes patient serum (Sanguine BioSciences, Valencia, CA, USA) was used for cDNA synthesis (RT; High-Capacity cDNA Reverse Transcription kits, Applied Biosystems). RT-PCR was performed as previously described report. ${ }^{11}$ Primer sequences are shown in Table 1. PCR products were separated by $1.5 \%$ agarose gel electrophoresis. 


\section{Determination of IHoP Protein by Western Blot and ELISA}

The $\alpha$ TC1.9 cell and IHoP-siRNA- $\alpha$ TC1.9 cell lysates were prepared using RIPA buffer with protease inhibitor cocktail (Sigma-Aldrich, St Louis, MO, USA). Immunoprecipitation of IHoP was performed on cell lysates following standard methodology. The cell lysates were incubated with IHoP antibody (prepared by GenScript, Piscataway, NJ, USA) and A/G agarose support (Santa Cruz Biotechnology, Santa Cruz, CA, USA). After precipitation, captured protein was eluted and then separated on a $12 \%$ acrylamide gel. The gels were stained with Coomassie blue to detect the protein product. Resulting bands were separated from the gel and analyzed by mass spectrometer. For western blotting, primary antibodies used included goat anti-glucagon (Santa Cruz Biotechnology), rabbit anti-actin (Abcam, Cambridge, MA, USA) and rabbit anti-IHoP (GenScript). HRP-conjugated donkey anti-goat and donkey anti-rabbit (Santa Cruz Biotechnology) were used as secondary antibodies. Signal was developed using ECL Prime (GE Healthcare, Pittsburgh, PA, USA). Indirect ELISA method was performed on conditioned media to analyze glucagon or IHoP secretion from $\alpha$ TC1.9 cells. The cells were initially cultured in $\alpha$ TC1.9 cell medium until 70\% confluent and then the medium was changed to FBS-free 0.5\% BSADMEM with variable glucose concentrations (2.75-25 mM) for $4 \mathrm{~h}$ incubations. For the detection of IHoP in human sera, indirect detection with alkaline phosphatase labeled antirabbit IgG (ProSci, Poway, CA, USA) was performed. After reacting with pNPP substrate solution ( $409 \mathrm{~nm}$; SigmaAldrich), quantitative analysis was determined from spectrophotometric readings (EnSpire, PerkinElmer, Shelton, CT, USA).

\section{Detection of IHoP Binding Genes by Yeast Two-Hybrid System and RNA-Binding Protein Immunoprecipitation}

A yeast two-hybrid library was constructed from mouse cDNA following the manufacturer's instructions (Clontech Laboratories, Mountain View, CA, USA). Gene identities were revealed by a Blast search in the Genebank database (PubMed-NCBI). IHoP's ability to bind mRNA was identified using a RNA-binding protein immunoprecipitation kit (Millipore, Billerica, MA, USA) and resulting mRNAs were deep-sequenced for identification (Genomics Research Center, University of Rochester, Rochester, NY, USA). For protein synthesis, full-length IHoP cDNA was inserted into pET-28(c)+ vector transfected into DE3 cells (Novagen, Cambridge, MA, USA) and induced by isopropyl $\beta$-D-1thiogalactopyranoside. IHoP protein was isolated with a HisTag binding system and Ni-column (Thermo Scientific, Rockford, IL, USA) following the manufacturer's protocol.

\section{Immunocytochemistry}

Immunostaining was performed according to previously described methods. ${ }^{11}$ IHoP protein was detected by immunofluorescent staining in cells cultured on chamber slides
(Nalgene, Rochester, NY, USA). The following antibodies were used: Rabbit anti-insulin (Santa Cruz Biotechnology), Goat or Rabbit anti-glucagon (Santa Cruz Biotechnology), mouse antiMHC-II (OX-6, Novus Biologicals, Littleton, CO, USA), glucose-6-phosphatase (Santa Cruz Biotechnology), and rabbit anti-IHoP (GenScript). Alexa Fluor 488 or 594 donkey antirabbit IgG and anti-goat IgG (1:500, Invitrogen) were used as secondary antibodies. Nuclei were identified by DAPI positivity (Vector Labs, Burlingame, CA, USA). Chromogenic detection was performed using the Vector-Elite $\mathrm{ABC}$ kit and $\mathrm{DAB}$ substrate with hematoxylin counterstaining.

\section{Glucose Tolerance Test}

All procedures involving animals were conducted according to institutionally approved protocols and guidelines. Mice (ICR/HaJ, Jackson Laboratory, Bar Harbor, ME, USA) were examined for blood glucose levels (FreeStyle, Abbott Diabetes Care, Alameda, CA, USA) after glucose challenge with or without IHoP protein treatment. The mice were divided into two groups $(n=5)$, and were fasted $6 \mathrm{~h}$ before experiments; one group received glucose ( $1 \mathrm{~g} / \mathrm{kg}$ body weight) by gavage while the other received glucose $(1 \mathrm{~g} / \mathrm{kg})$ by gavage plus IHoP protein $(1 \mu \mathrm{g} / \mathrm{kg}$ body weight $)$ by tail vein injection. Blood glucose measurements of all the mice were screened before treatment and 60, 90, 120, and $180 \mathrm{~min}$ after treatment.

\section{Preparation and Injection of IHoP-siRNA into NOD Mice} Female NOD/ShiLtJ mice (8 weeks) were purchased from Jackson Laboratory. Monitoring of blood glucose levels began at 10 weeks of age. Preparation and injection of IHoP-siRNA was performed following previously described methods. ${ }^{11}$ Blood glucose levels were tested before siRNA injection. NOD mice were divided into three groups: pre-onset scramble siRNA treated (control, $n=4$ ), pre-onset IHoP-siRNA treated $(n=5)$, and post-onset with blood glucose levels more than $250 \mathrm{mg} / \mathrm{dl}$, IHoP-siRNA treated $(n=5)$. All injections were performed via tail vein (50 $\mu$ g per animal). Blood glucose levels were monitored every 2 days after injection for 35 weeks total or until killing was humanely required.

\section{Detection of Regenerative Islet 3 gamma using In Situ RT-PCR}

Direct in situ RT-PCR detection of regenerating islet 3 gamma (Reg $3 \gamma$ ) mRNA expression was examined in formalin-fixed, paraffin-embedded tissues. Reverse transcriptase and detection was performed as previously described. ${ }^{12}$

\section{Adoptive Transfer}

Single-cell suspensions of splenocytes isolated from spontaneously diabetic NOD/shiLtj female and NOD/shiLtj-treated IHoP-siRNA donors were prepared as previously reported. ${ }^{13}$ Donor spleen cells $\left(8 \times 10^{6}\right.$ viable cells $)$ were injected via the tail vein into 8 -week-old NOD/LtSz-scid female mice. Blood glucose levels were monitored every 3 days after injection for 
a total of 9 weeks. For pathologic evaluation of pancreatic islets, tissue from recipient mice was fixed in neutral buffered formalin, embedded in paraffin, cut at $5 \mu \mathrm{m}$ and stained with H\&E. ${ }^{14}$

a

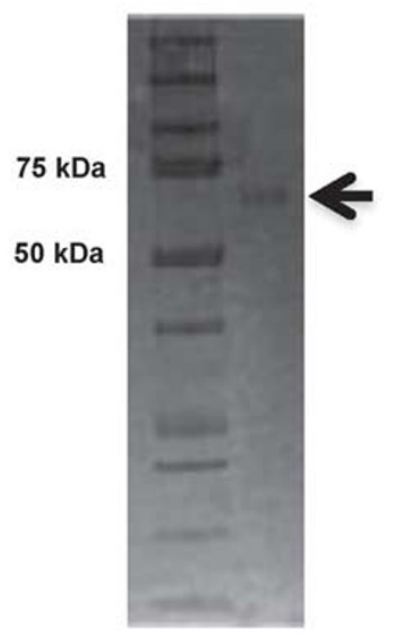

\section{Statistical Analysis}

The values are expressed as mean+s.d. Statistical differences were analyzed using ANOVA and Student's $t$-test. $P<0.05$ was considered statistically significant.

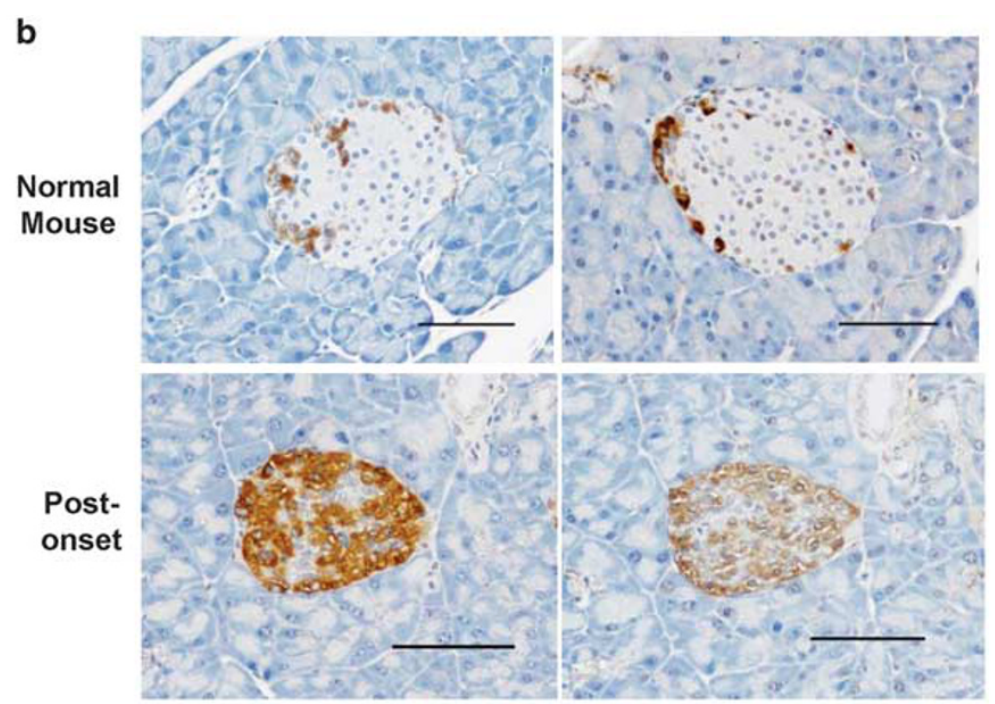

Glucagon

IHoP c

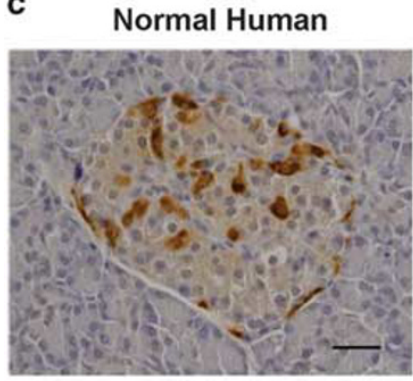

Glucagon
Type 1 Diabetes

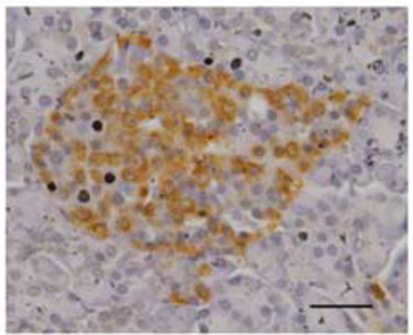

Glucagon
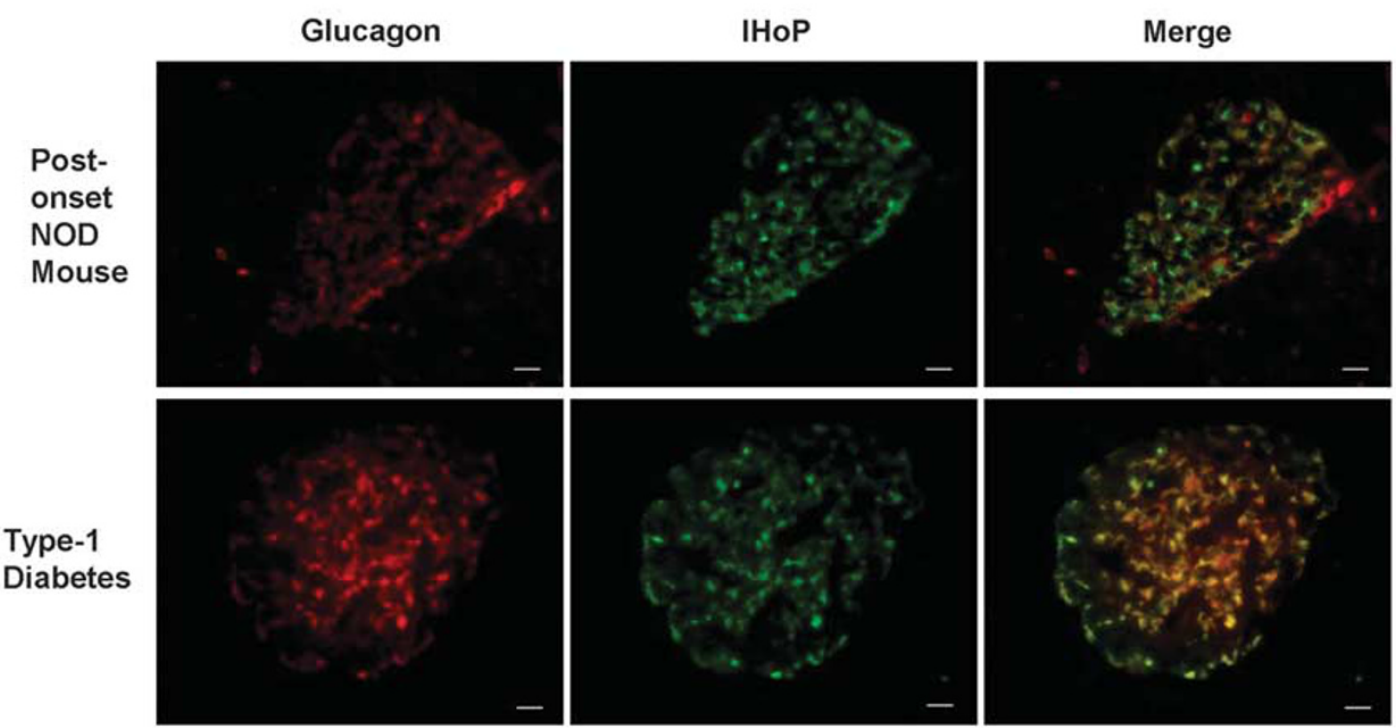

Normal Human

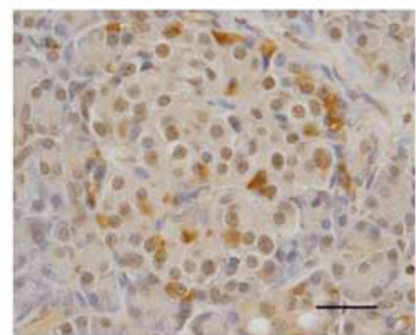

Type 1 Diabetes

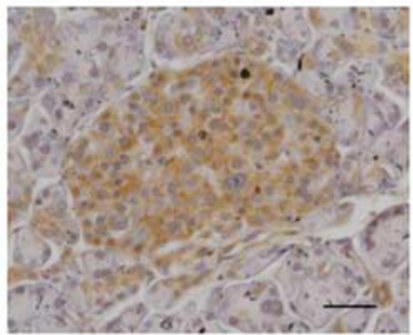

IHoP

d 


\section{RESULTS}

\section{Glucagon and IHoP are Co- and Overexpressed in Diabetic Islets}

We first confirmed the presence of IHoP in pancreatic $\alpha$-cells and demonstrated the specificity of our primary antibody. Immunoprecipitation detected IHoP in lysate from $\alpha \mathrm{TC} 1.9$ (Figure 1a). We isolated a single protein product on $12 \%$ SDS-PAGE gel sized at $63 \mathrm{kDa}$, and established its identity by mass spectrometry.

We next determined IHoP expression patterns from normal and diabetic islets; these results were consistent with previous studies. ${ }^{11}$ In Figure 1b, $10-15 \%$ of cells within the normal mouse pancreatic islet expressed glucagon and an equal percentage expressed IHoP. However in the pancreatic islet of post-onset NOD mice, positivity increased to $50 \%$ of the islet cells (Figure 1b; post-onset). The same pattern of increased glucagon and IHoP expression was detected in tissue from a type 1 diabetes patient. In normal human pancreatic islets, glucagon and $\mathrm{IHoP}$ expressing cells were both localized to the islet periphery (Figure 1c; normal human); whereas in the patients with type 1 diabetes, much of the islet was replaced with glucagon/IHoP dual positive cells (Figure 1c; type 1 diabetes). Suspected $\mathrm{IHoP}$ and glucagon colocalization was confirmed by immunofluorescent co-staining (Figure 1d). Our results indicated that within the islet, IHoP is a pancreatic $\alpha$-cell specific transcript that dramatically increases in diabetes.

\section{IHoP Induces the Release of Glucagon from $a \mathrm{TC1} .9$ Cells Under High-Glucose Conditions}

Mouse-derived $\alpha \mathrm{TC} 1.9$ and $\beta \mathrm{TC} 6$ cell lines were used to characterize the relationship between IHoP, glucagon, and glucose levels. RT-PCR confirmed gene expression of glucagon and IHoP to be restricted to $\alpha \mathrm{TC} 1.9$ cells, while insulin expression was $\beta$ TC6 cell specific (Figure 2a). Immunocytochemistry confirmed these results; $\alpha$-cells stained positive for glucagon and IHoP while $\beta$-cells were positive for insulin but negative for IHoP (Figure $2 \mathrm{~b}$ ). To test the sensitivity of IHoP release in response to glucose stimulation, we cultured $\alpha \mathrm{TC} 1.9$ cells under a range of glucose conditions. Low-glucose conditions $(2.75 \mathrm{mM})$ induced low levels of IHoP secretion as measured by indirect ELISA, while cells cultured in increasingly higher glucose concentrations (5.5 to $25 \mathrm{mM}$ ) released correspondingly higher amounts of IHoP (Figure 2c). To determine whether IHoP had an effect on $\alpha$-cell proliferation (Figure 2d), we performed a proliferation assays in which alpha cells were cultured in standard 10\% FBS media (white bars); serumdeprived $0.5 \%$ BSA media (black bars); or IHoP supplemented $0.5 \%$ serum media (gray bars). The readings were collected at 24, 48, and $72 \mathrm{~h}$ time points. No significant differences in proliferation were found between the $0.5 \%$ BSA and $\mathrm{IHoP}$ containing cultures at any time point. This observation indicates that in and of itself, IHoP does not result in a sustained alpha cell proliferation response as compared with $10 \%$ FBS, which does. Next, we tested the impact IHoP had on glucagon secretion from $\alpha$-cells (Figure 2e). Under high-glucose conditions, glucagon secretion was significantly increased in the presence of $\mathrm{IHoP}$, emphasizing that IHoP has a role in controlling glucagon secretion. Conversely, we silenced $\mathrm{IHoP}$ in $\alpha \mathrm{TC} 1.9$ cells using a siRNA construct. Glucagon protein was detected in $\alpha \mathrm{TC} 1.9$ cells by western blot but transduction with IHoP-siRNA eliminated glucagon expression (Figure 2f, IHoP-siRNA $\alpha \mathrm{TC1.9)}$. Taken together, these results demonstrate that in vitro, IHoP regulates $\alpha$-cell secretion of glucagon in response to high-glucose levels.

\section{Prevention of Hyperglycemia by Suppression of IHoP in Pre-Onset NOD Mice}

To examine the ability of IHoP to inhibit the progression of diabetes, we used NOD mice as our type 1 diabetes model. $\mathrm{NOD} /$ shiLtj mice consistently and spontaneously develop diabetes with insulitis and leukocytic infiltration in their pancreatic islets. Nine-week-old pre-onset mice were divided into two groups; a control group which received tail vein injection with scramble siRNA (scramble siRNA), and a treated group that received IHoP-siRNA (pre-onset IHoPsiRNA). A post-onset diabetic group of NOD mice (blood glucose levels over $250 \mathrm{mg} / \mathrm{dl}$ ) also received IHoP-siRNA (post-onset IHoP-siRNA). Following siRNA injection, blood glucose levels were measured biweekly during a 35-week experimental period (Figure 3a). Pre-onset mice administered IHoP-siRNA consistently demonstrated even lower blood glucose levels $(73+6.69 \mathrm{mg} / \mathrm{dl})$ than did wild-type mice $(91$ $+7.62 \mathrm{mg} / \mathrm{dl}$ ). However, IHoP-siRNA could not normalize glucose levels in post-onset NOD mice. Scramble siRNAtreated pre-onset NOD mice developed hyperglycemia in keeping with the expectations for this model. These results indicated that a single systemic treatment with IHoP can impede the development of type 1 diabetes, but cannot reverse it once the islet is destroyed.

Figure 1 Islet homeostasis protein (IHoP) expression in mouse and human pancreatic islets. (a) IHoP immunoprecipitation with protein extracted from aTC1.9 cells (mouse-derived alpha cell line); arrow designates a single band product at $63 \mathrm{kDa}$. (b) Normal mouse (left panels) and diabetic NOD mouse islets (right panels; post-onset) stained for glucagon (brown) and IHoP (brown). (c) Normal human and type 1 diabetes patient pancreas tissues stained for glucagon (brown) and IHoP (brown) (Pancreas tissue was a generous gift from Dr Roberto Gianami, University of Colorado Health Science Center, Denver, CO, USA). Nuclei counterstained with hematoxylin (blue). Scale bars, $50 \mu \mathrm{m}$ (b) and $20 \mu \mathrm{m}$ (c). (d) Co-localization of glucagon and IHoP expression in pancreatic tissue from a post-onset NOD mouse and a type 1 diabetes patient. Post-onset NOD mouse and type 1 diabetes patient pancreas tissues stained for glucagon (red), IHoP (green), and merged (yellow). Nuclei were counterstained with DAPI (blue). Scale bars, $20 \mu \mathrm{m}$. 
a

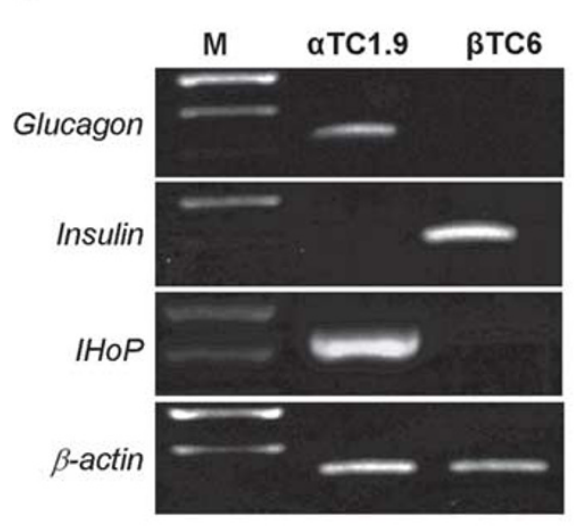

d

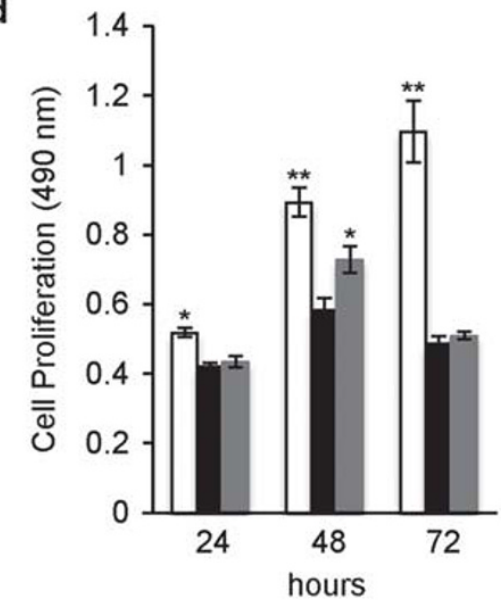

b
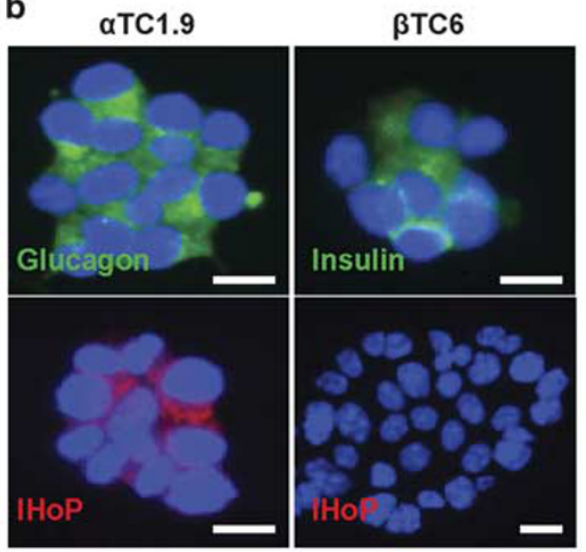

e

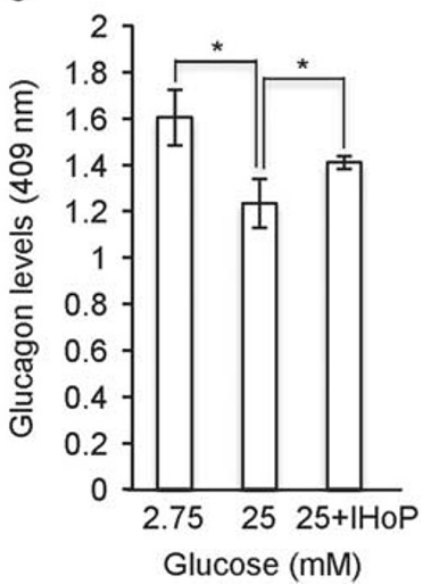

c

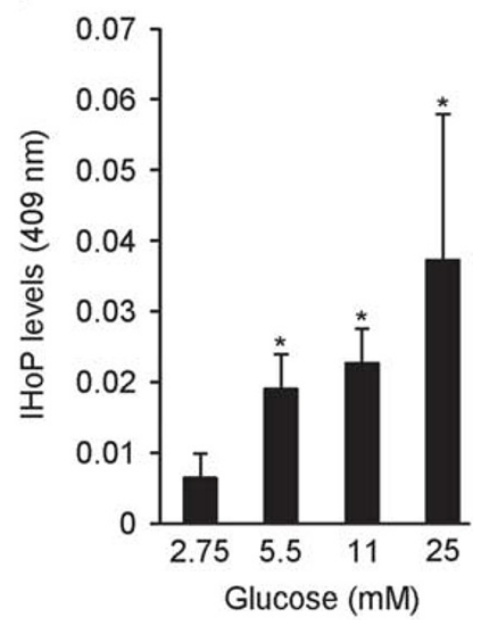

f

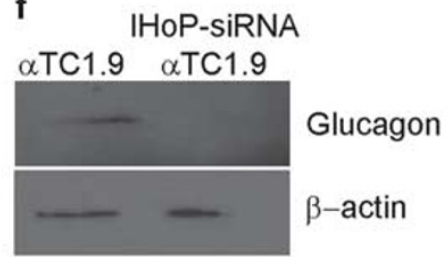

Figure 2 Detection of $I H o P$ gene and induction of IHoP secretion from glucagon-synthesizing $a$-cells. (a) RT-PCR analysis of $I H o P$ gene expression in aTC1.9 and $\beta$ TC6 cells. $\beta$-Actin as internal control. M indicates 100 bp ladder. (b) ICC detection of IHoP protein in aTC1.9 and $\beta$ TC6 cells. Nuclei were counterstained with DAPI (blue). Scale bars, $10 \mu \mathrm{m}$. (c) ELISA measurements of IHoP secreted by aTC1.9 cells following $4 \mathrm{~h}$ of culture in different glucose concentrations (2.75-25 mM). Data were compared within each glucose concentration group. (d) Effect of IHoP protein on aTC1.9 cell proliferation. The aTC1.9 cells were cultured in high-glucose DMEM media with $10 \%$ FBS (white bar), with $0.5 \%$ BSA (black bar) or with IHoP protein (1 $\mu$ g/ml) in $0.5 \%$ BSA medium (gray bar), for 24, 48, and $72 \mathrm{~h}$. Data were compared within each experimental group at given time points. (e) ELISA analysis of glucagon secretion from aTC1.9 cells following treatment with IHoP protein. The aTC1.9 cells were cultured in low-glucose medium (2.75 mM), high-glucose medium $(25 \mathrm{mM})$, and high-glucose medium $(25 \mathrm{mM})$ with IHoP $(1 \mu \mathrm{g} / \mathrm{ml})$ for $2 \mathrm{~h}$. Data were compared within each experimental group. Data represent the mean+s.d. within time groups $(n=5)$. The $P$-values generated for $(\mathbf{c}-\mathbf{e})$ are designated by ${ }^{*} P<0.05$ and ${ }^{* *} P<0.01$. (f) Western blot analysis detecting glucagon protein in $a \mathrm{TC} 1.9$ cell lysates with or without transduced IHoP-siRNA. $\beta$-Actin as loading control.

A secondary source of systemic glucose comes from the liver via a process utilizing glucose-6-phosphatase (G6Pase), the key enzyme responsible for releasing stored glucose from hepatocytes. We tested G6Pase expression in liver tissue excised from both IHoP-siRNA-treated experimental groups (pre-onset and post-onset). G6Pase was detected in a majority of post-onset NOD mouse hepatocytes, whereas the pre-onset IHoP-siRNAtreated NOD mice displayed downregulated G6Pase activity (Figure 3b). Systemically silencing IHoP lowered both G6Pase activities in the liver and glucose levels in the blood.

\section{In Vivo Induction of Hyperglycemia in the Presence of Overexpressed IHoP}

We examined the effect of $\mathrm{IHoP}$ on normal mice during glucose challenge (Figure 3c). Normoglycemic mice received
$1 \mathrm{~g} / \mathrm{kg}$ glucose gavage with or without a concomitant tail vein injection of IHoP recombinant protein $(1 \mu \mathrm{g} / \mathrm{kg})$. Blood glucose levels were analyzed at intervals for $180 \mathrm{~min}$. Sixty minutes after gavage, the control mice showed elevated blood glucose levels $(162+31.28 \mathrm{mg} / \mathrm{dl})$. Similarly, mice treated with $\mathrm{IHoP}$ protein in tandem with glucose challenge had increased blood glucose levels $(179.4+63.44 \mathrm{mg} / \mathrm{dl})$. At $90 \mathrm{~min}$, the glucose-challenged untreated mice glucose levels dropped to near normal levels $(124.4+10.97 \mathrm{mg} / \mathrm{dl})$. In contrast, glucosechallenged mice administered IHoP maintained elevated levels of blood glucose at $90 \mathrm{~min}(183.8+19.02 \mathrm{mg} / \mathrm{dl})$ and continued to do so $120 \mathrm{~min}$ after treatment $(141.2+18.51 \mathrm{mg} / \mathrm{dl} v s 116.8$ $+11.54 \mathrm{mg} / \mathrm{dl}$ ). At $180 \mathrm{~min}$, blood glucose levels had returned to baseline in both the groups. These results indicate involvement of IHoP in modulating glucose levels in vivo. 


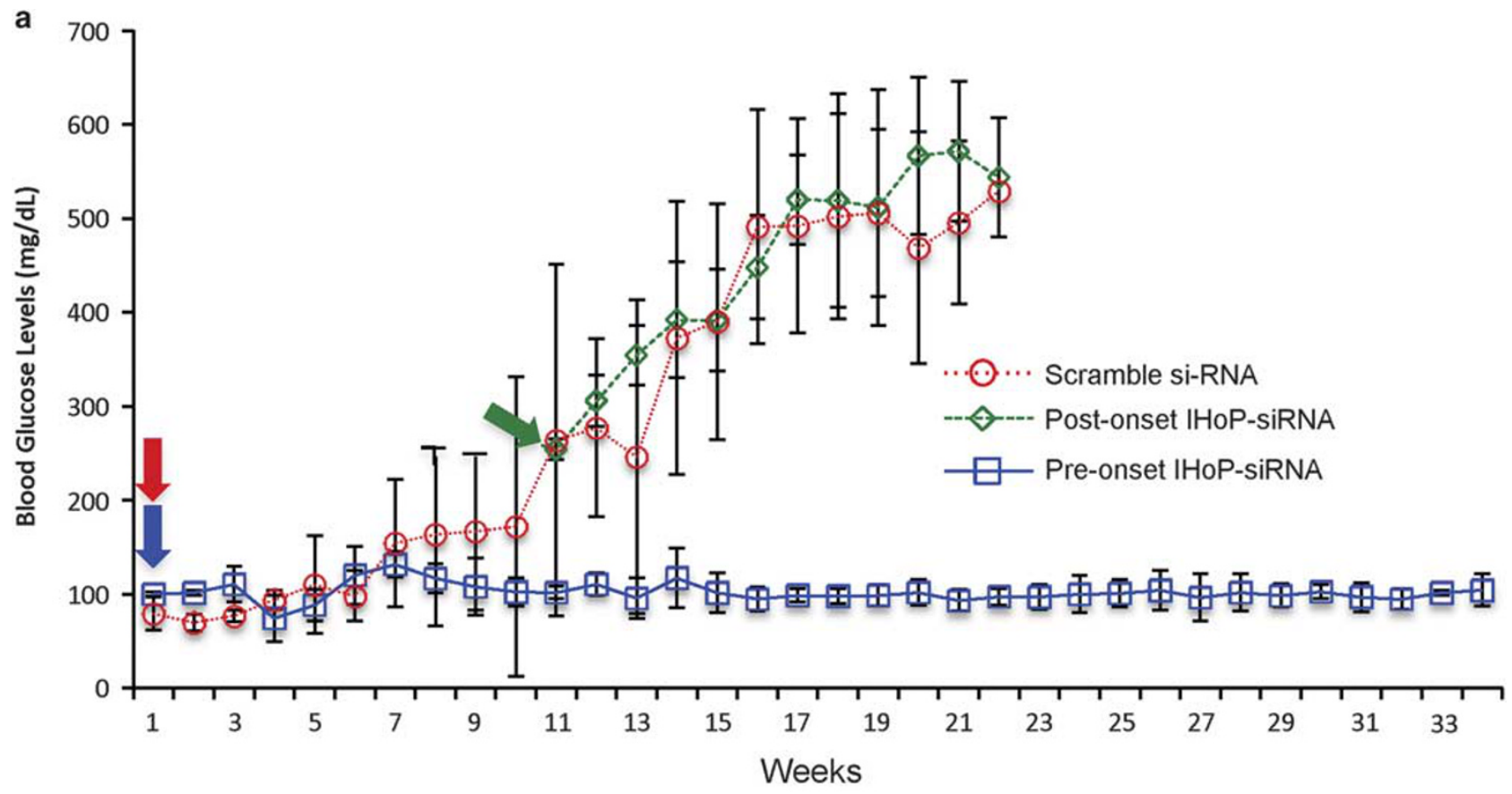

b

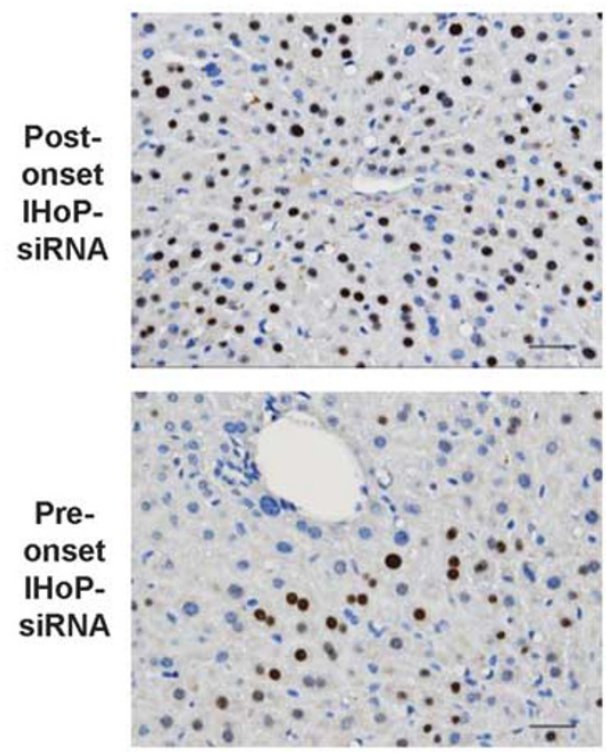

C

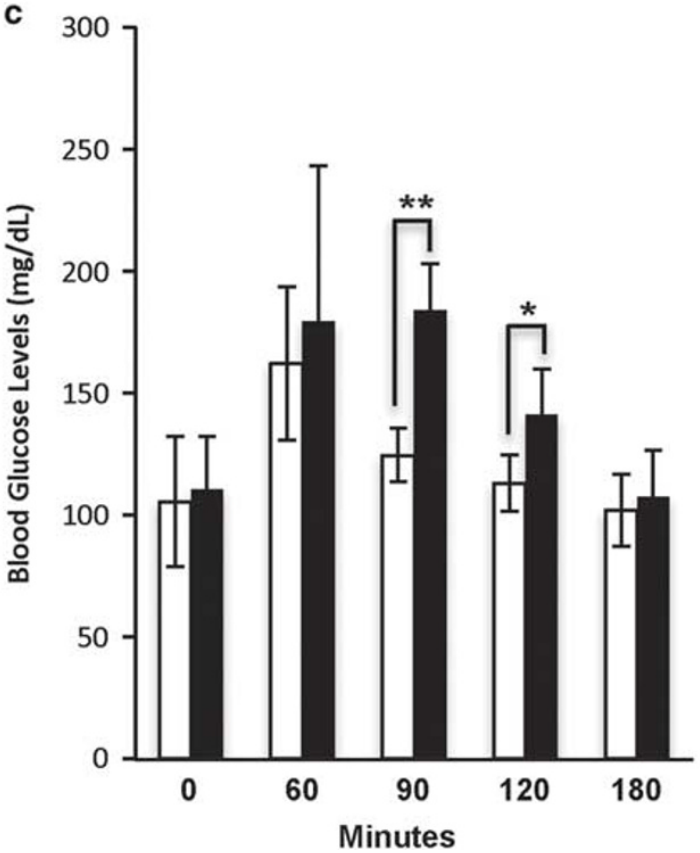

Figure 3 The effectiveness of IHoP in preventing hyperglycemia in pre-onset NOD mice treated with an IHoP-siRNA construct. (a) NOD mice were placed into three groups; (1) pre-onset mice (glucose below $100 \mathrm{mg} / \mathrm{dl}$ ) receiving scrambled construct, as controls (open red circles; $n=4$ ); (2) post-onset mice (glucose above $250 \mathrm{mg} / \mathrm{dl}$ ) receiving IHoP-siRNA (open green diamonds; $n=5$ ), and (3) pre-onset mice receiving IHoP-siRNA (open blue squares; $n=5$ ). Arrows indicate siRNA injection and color corresponds to treatment group. (b) Glucose-6-phosphatase expression (dark brown in nuclei) in livers from NOD mice treated with IHoP-siRNA. Pre-onset IHoP-siRNA-treated mice had very few hepatocytes stained positively for glucose-6-phosphatase. Nuclei were counterstained with hematoxylin (blue). Scale bars, $20 \mu \mathrm{m}$. (c) Blood glucose levels were measured in glucose-challenged (1 g/kg) control mice (white bars) and challenged mice concurrently given i.v. IHoP protein ( $1 \mu \mathrm{g} / \mathrm{kg}$; black bars). Data are represented as mean+s.d. of blood glucose levels $(n=5) .{ }^{*} P<0.01,{ }^{* *} P<0.05$. 


\section{IHoP Effects Major Histocompatibility Complex II Expression in the Islets of Post-Onset NOD Mice}

MHC class II is a known marker for the recruitment of T cells and drives the eventual autoimmune attack and destruction of insulin-producing $\alpha$-cells in type 1 diabetes. Under normal conditions islets do not express MHC class II (Figure 4a, normal). We sought to investigate a potential connection between IHoP and MHC class II to see whether regulation of IHoP ameliorated the autoimmune signaled attack on pancreatic islets seen in our diabetic mice. In post-onset NOD mice, expression of glucagon (green) and MHC Class II (red) was co-localized within pancreatic $\alpha$-cells (Figure 4a). MHC Class II immunohistochemistry performed on normal mouse pancreatic tissue (Figure $4 \mathrm{~b}$ left panel); pre-onset IHoP-siRNA-treated NOD mice (Figure $4 \mathrm{~b}$, right panel), and post-onset diabetic pancreatic tissue (Figure $4 \mathrm{~b}$, center panel), revealed that siRNA-treated pre-onset mice were negative for MHC class II. However post-onset islets stained strongly for MHC Class II. The IHoP-siRNA-treated animal tissue was observed to be closer in staining pattern and intensity to normal islets. IHoP-siRNA treatment in pre-onset NOD mice resulted in pancreatic islets devoid of MHC Class II expression and lacking immune cell infiltration.

We performed an adoptive transfer experiment to investigate the effect IHoP has on T-cell activation during diabetes progression. NOD/LtSz-scid mice do not spontaneously develop diabetes and have normal islets (Figure 4c, left panel and Figure 4d, control bar). In contrast, transplanting these mice with diabetic NOD/shiLtj derived splenocytes caused hyperglycemia and massive islet immune infiltration 4 weeks after transplantation (Figure 4c, middle panel and Figure 4d, Diabetic ATx, middle bar). When 7-week post-treated IHoP-siRNA NOD mouse-derived splenocytes were transplanted into NOD/LtSz-scid mice, the animals remained normoglycemic with immunologic responses restricted to the islet periphery (Figure 4c, right panel and Figure 4d, IHoP-siRNA ATx right bar). The control group showed no insulitis (score 0, Figure 4e; control). The diabetic NOD/shiLtj derived splenocyte recipient islets developed intermediate to complete insulitis (score 3.25, Figure 4e; Diabetic ATx). IHoP-siRNA-treated splenocyte recipients displayed relatively benign peri-islet insulitis (score 1.13, Figure 4e; IHoP-siRNA ATx). Insulitis raw data are provided in Supplementary Table 2. Each slide utilized to count islets had at least four sections from each animal used in the study $(n=3-4)$. A total of 89 islets were counted in the control group, whereas in the siRNA-treated group a total number of 73 islets were counted. In the scrambled group, a total number of 92 islets were counted. After an extended period of time ( $>8$ weeks), all recipient mice eventually developed diabetes (data not shown). There was no significant difference in the levels of hyperglycemia between the two groups once full-onset diabetes ensued. We noted that in post-onset NOD islets, glucagon-positive cells appeared to coexpress MHC class II (Figure 4a). RT-PCR analysis (Figure 4f) confirmed that scrambled constructs have elevated levels of MHC Class II expression; however, IHoP-siRNA treatment suppressed MHC class II gene expression, indicating that IHoP does effect MHC class II expression.

\section{Detection of Reg $3 \gamma$ and PDX-1 Expression in the Islet}

Using a yeast two-hybrid system, we identified proteins that directly or indirectly bound with IHoP (Supplementary Table 3). The most intriguing of these was Reg $3 \gamma .{ }^{15}$ To determine whether Reg $3 \gamma$ has a role in the recovery of pancreatic islets after IHoP-siRNA treatment in NOD mice, we first performed RT-PCR on $\alpha \mathrm{TC} 1.9$ and IHoP-siRNA-transduced $\alpha \mathrm{TC} 1.9$ cells. The $\alpha \mathrm{TC} 1.9$ cells expressed a negligible amount of Reg $3 \gamma$, whereas IHoP-siRNA-transduced $\alpha$ TC1.9 generated a very strong Reg $3 \gamma$ signal (Figure $5 \mathrm{a}$ ). In addition, we performed in situ hybridization for Reg $3 \gamma$ gene expression in both normal and pre-onset IHoP-siRNA-treated NOD mice. Figure $5 \mathrm{~b}$ shows that Reg $3 \gamma$ expression was rarely observed in the normal islet, however, in pre-onset IHoP-siRNA-treated NOD mice islets, Reg $3 \gamma$ expression levels were highly elevated in the $\beta$-cell population. Furthermore, to determine whether the presence of $\mathrm{IHoP}$ could normalize $\beta$-cell function, we preformed immunofluorescence for PDX-1 ( $\beta$-cell maturation marker) and insulin. The islets of treated mice were positive for both PDX-1 and insulin (Figure $5 \mathrm{c}$ and d); Figure 5e shows only PDX-1 (arrows) and nuclei (blue). Finally, in Figure 5f, when we counted the number of islets and compared treated and untreated groups, it was revealed that the untreated post-onset NOD mice showed a lower total number of islets per section $(0.88+1.21$ islets, black bar $)$ and these islets rarely expressed PDX-1 $(0.38+0.51$ islets, black bar). However, the treated mice group yielded a larger number of islets (14.44+8.82 islets; white bar), and these islets expressed a greater number of PDX-1-positive cells (19.88 +9.71 islet; white bar). These results indicated that decreasing IHoP expression at an early time point slows the progression of the disease, allowing damaged islets the opportunity to restore and thereby improves islet functionality.

\section{IHoP as a Potential Biomarker for Detecting Type 1 Diabetes in Patients}

We analyzed type 1 diabetes patient samples for the presence of IHoP using both ELISA and RT-PCR approaches. Initially, IHoP mRNA extracted from a type 1 diabetes patient's pancreas was compared with $I H o P$ gene expression in the mouse $\alpha \mathrm{TC} 1.9$ cell line. RT-PCR analysis showed that the type 1 diabetes patient tissue and the mouse alpha cell line expressed the $I H o P$ gene identically in band size and pattern (Figure 6a), with no expression of L-Plastin. Next, sera were tested for the presence of secreted IHoP. In a sample group consisting of two nondiabetic and eight full-onset type 1 diabetes cases (four males and four females with an age range of 5-50 years old, de-identified sample gifts from the University of Florida's Diabetes Institute), RT-PCR analysis netted IHoP positivity in all type 1 diabetes patients 
a

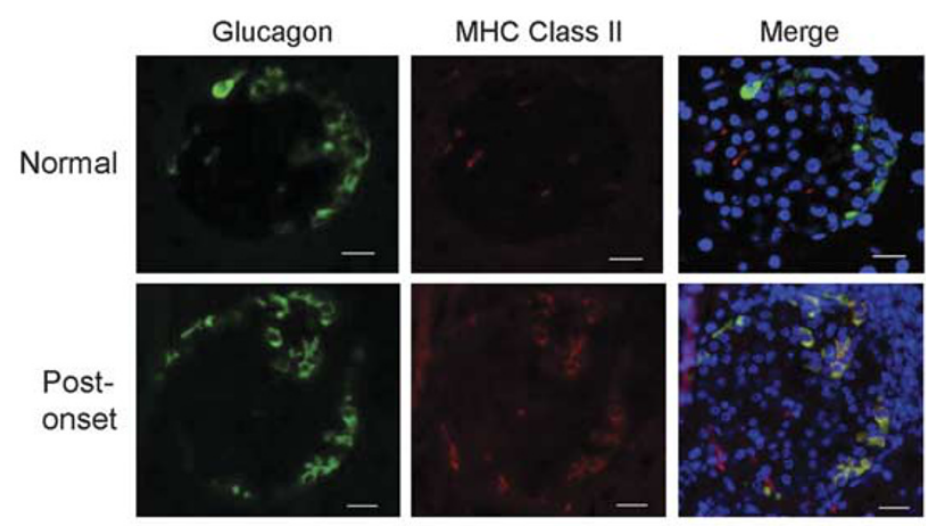

b

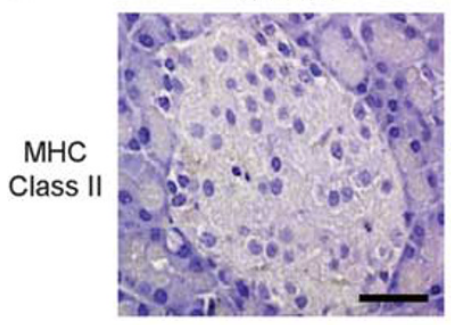

C

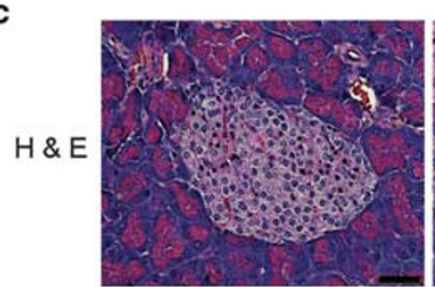

Control

Normal
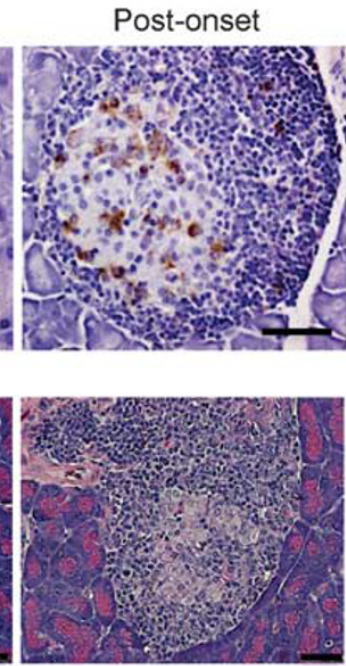

Diabetic ATx
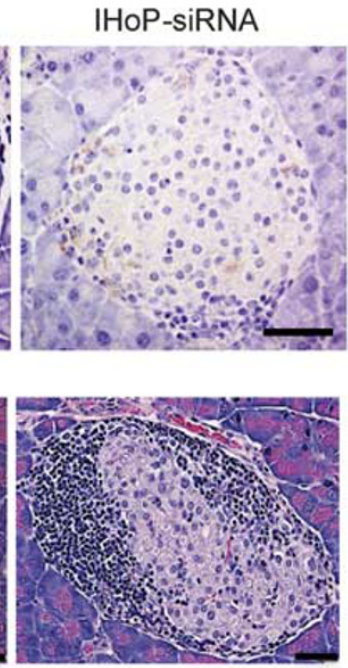

IHoP-siRNAATx

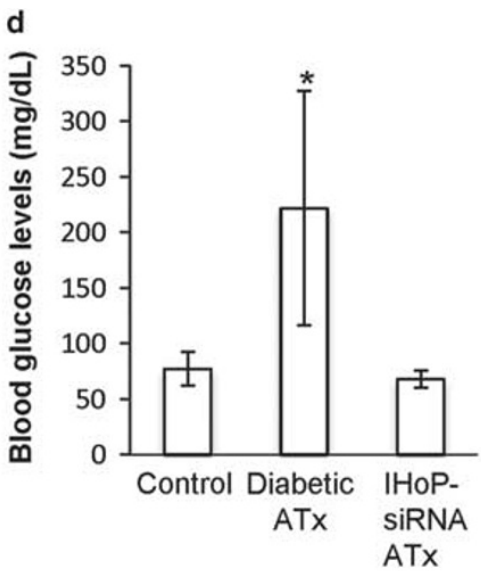

e

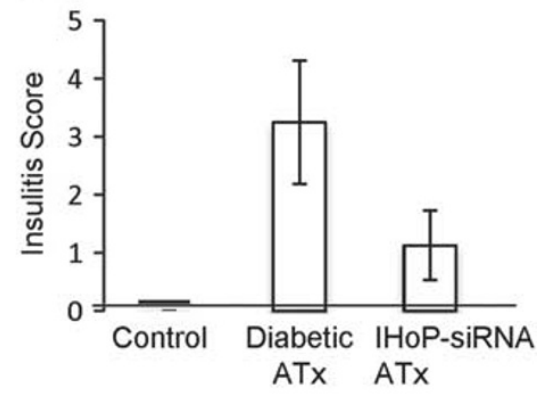

f

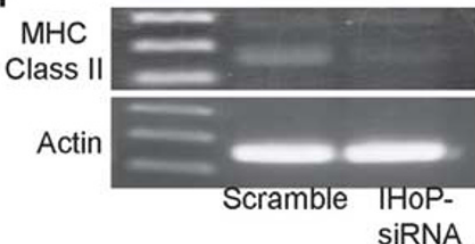

Figure 4 Immune response in NOD mice treated with an IHoP- siRNA construct. (a) Immunofluorescence staining for glucagon (green) and MHC Class II (red) was performed on normal and post-onset NOD islets. Nuclei were counterstained with DAPI (blue) Scale bars, $20 \mu \mathrm{m}$. (b) IHC showing MHC Class II expression in normal, post-onset NOD and IHoP-siRNA-treated NOD mice islets. Nuclei were counterstained with hematoxylin (blue). Scale bars, $40 \mu \mathrm{m}$. (c) Adoptive transfer of splenocytes produced the following three cohorts: (1) control; NOD/LtSz-scid recipient alone. (2) Diabetic ATx; diabetic NOD/ shiLtj donor into NOD/LtSz-scid recipient. (3) IHoP-siRNA ATx; pre-diabetic NOD/shiLtj at 7 weeks post IHoP-siRNA injection donor into NOD/LtSz-scid recipient. Center panel: when control splenocytes were given to NOD mice, the recipient mice developed diabetes and showed massive immunologic response within islets (Diabetic ATx). Right panel: in mice that received IHoP- siRNA donor splenocytes, immune cells became activated and surrounded the islet but did not invade (IHoP-siRNA ATx). Hematoxylin and eosin staining from tissue collected 4 weeks post transplantation. Scale bars, $20 \mu \mathrm{m}$. (d) To confirm the results seen in (c), blood glucose levels of all three cohorts were tested. At 4 weeks post transplantation, glucose levels in IHoP-siRNA adoptive transferred animals (IHoP-siRNA ATx) were comparable to those of control mice. In contrast, non-treated animals became hyperglycemic. ${ }^{*} P<0.05$. (e) Insulitis in adoptive transferred mice. Control mice showed no insulitis and were scored as 0 , the mice that received diabetic donor splenocytes scored 3.25 and IHoP-siRNA mouse-derived splenocyte recipients scored 1.13. (f) Glucagon-synthesizing mouse aTC1.9 cells were used to determine the effects of IHoP-siRNA transduction on MHC Class II gene expression in vitro. In agreement with in vivo results (b), aTC1.9 cells transducing the IHoP-siRNA construct (IHoP-siRNA) downregulated MHC Class II expression. $\beta$-Actin was used as loading control.

tested (Figure 6b; type 1 diabetes lanes). IHoP product was not detected in the nondiabetic human serum (Figure 6b; N). A no RT step negative control was included, and no product contaminants were detected (Figure $6 \mathrm{~b}$ and $\mathrm{c}$ ). In addition, we tested IHoP concentrations in type 1 diabetes serum by indirect ELISA (Figure 6c). Four nondiabetic and four type 1 diabetes patient sera were analyzed for blood glucose, insulin, and IHoP levels. Nondiabetic controls were found to have low levels of all three metabolites in their sera (Figure 6c, blue box). The type 1 diabetes patients had significantly higher blood glucose and IHoP levels (Figure 6c, red box). The data indicate a positive correlation between increased levels of blood glucose and elevated levels of IHoP, suggesting a potential role for $\mathrm{IHoP}$ as a type 1 diabetes biomarker. To further support the usefulness of IHoP as a potential biomarker, we performed a blinded analysis on 16 serum samples from either diabetic control/relatives or newly diagnosed early-stage T1D patients (Supplementary Table 4). The results yielded one false positive in the control group and one false negative in the diabetic group. We cannot 
a

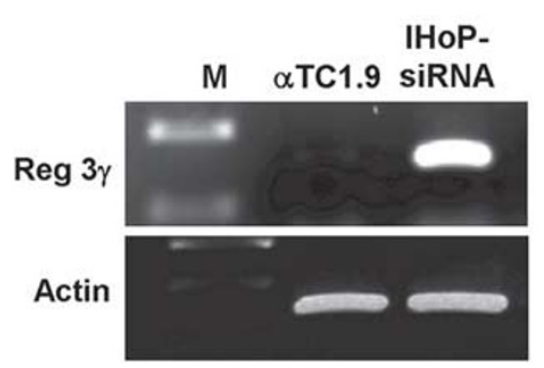

b
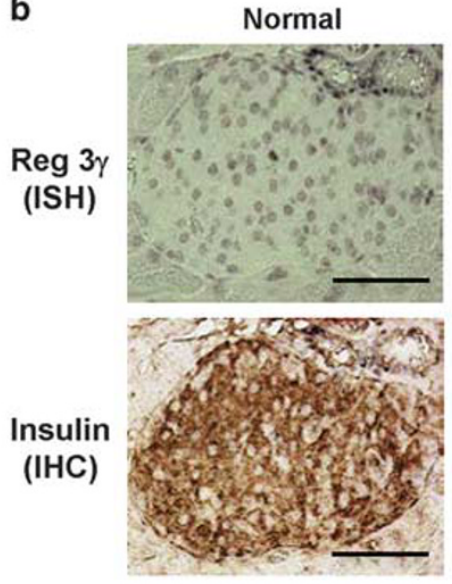

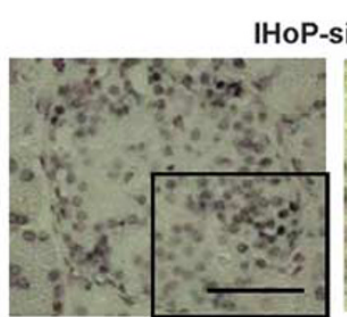

IHoP-siRNA
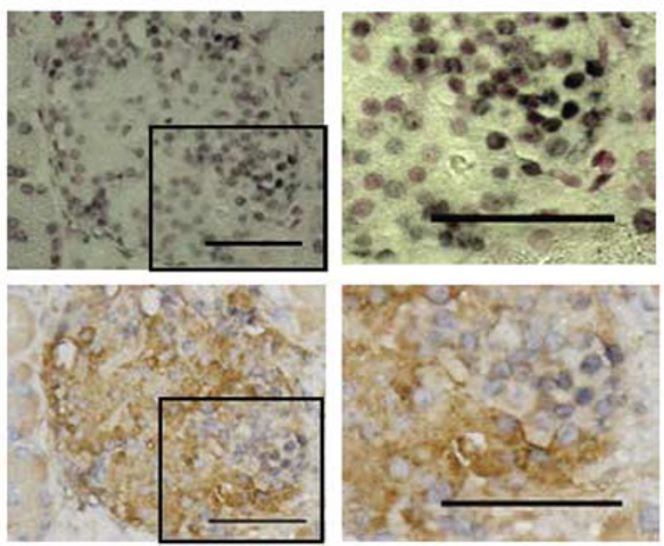
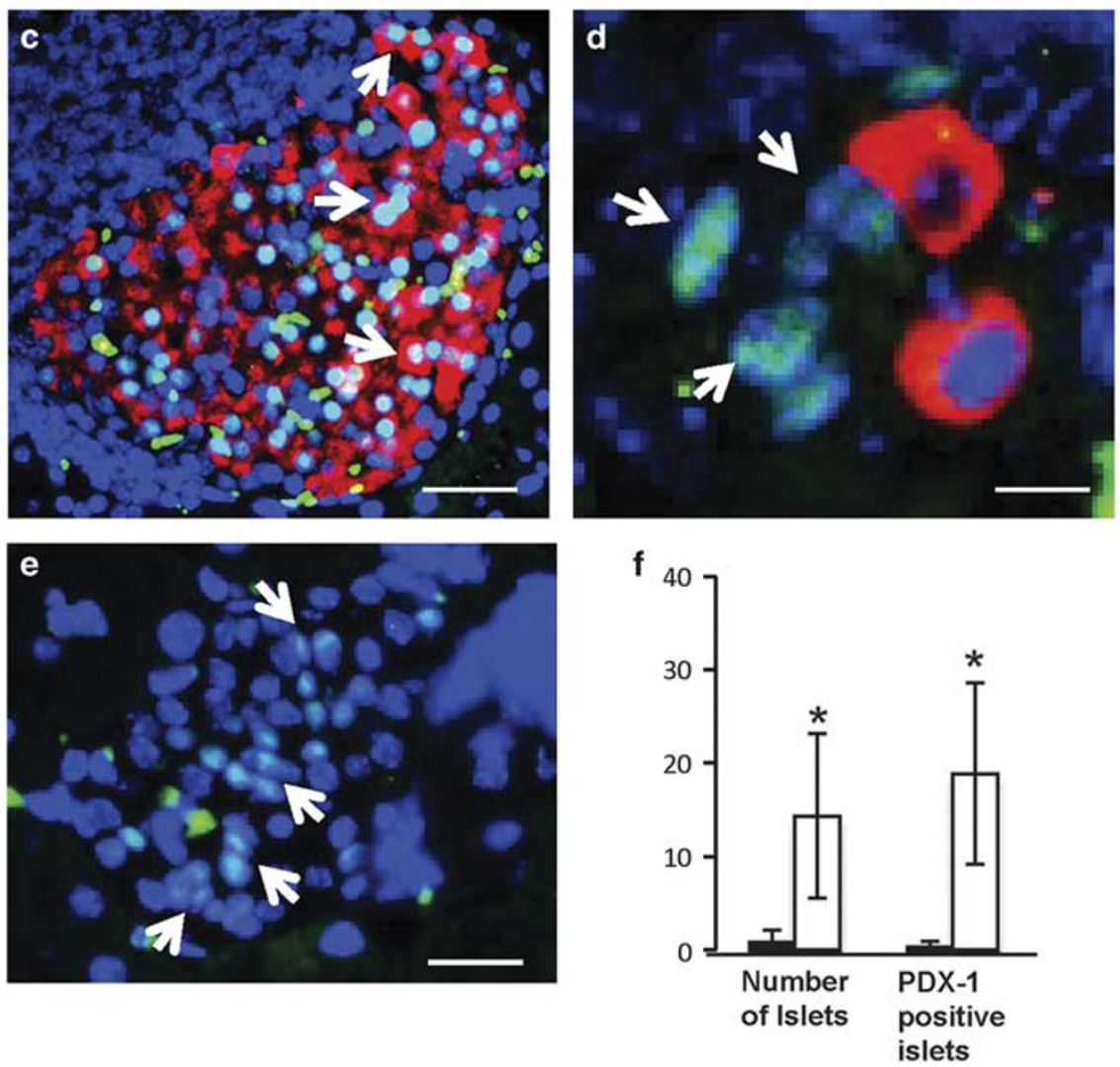

Figure 5 Detection of islet regeneration in pre-onset IHoP-siRNA-treated NOD mice islets. (a) RT-PCR analysis of Reg $3 \gamma$ in aTC1.9 and IHoP-siRNAtransduced $a \mathrm{TC} 1.9$ cells with $\beta$-actin as loading control. M indicates 100 bp ladder. (b) Detection of Reg $3 \gamma$ (purple) by in situ RT-PCR hybridization. Nuclei were counterstained with nuclear fast red (pink). Insulin IHC staining (brown) was performed sequentially to identify the islets. (c-e) Islets of pre-onset IHoP-siRNA-treated NOD mice were positive for both PDX-1 (green) and insulin (red). White arrows indicate PDX-1 and insulin-positive staining (c). In higher magnification (d), the arrows identify PDX-1-positive cells (green) that are negative for insulin (red). (e) A single lower magnification image showing a global view of an islet containing several PDX-1+ cells. Nuclei are stained with DAPI (blue). Scale bars, $20 \mu \mathrm{m}$ (b, c and e) and $10 \mu \mathrm{m}$ (d). (f) Quantification of PDX-1-expressing islets. Total islet counts were quantified from H\&E stains while IHC was used to stain for and count PDX-1-positive islets. Black bars indicate untreated post-onset NOD mice islets and white bars indicate pre-onset siRNA-IHoP-treated NOD mice pancreatic islets (10 sections each; $n=4-5$ per group). Data represent. mean+s.d. within group. ${ }^{*} P<0.05$.

ascertain whether the false positive patient went on to develop T1D, but they did test positively for one of the diagnostic diabetic autoantibodies reported, indicating that an autoimmune process did exist. Two patients that were positive for a single diagnostic autoantibody and another patient positive for two autoantibodies were correctly identified by IHoP serum levels. What this testing does reveal is that IHoP was detectable in serum at the earliest 
a

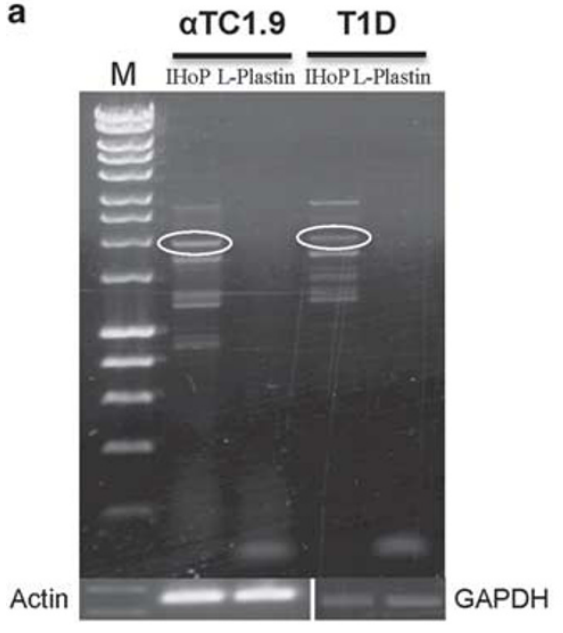

C
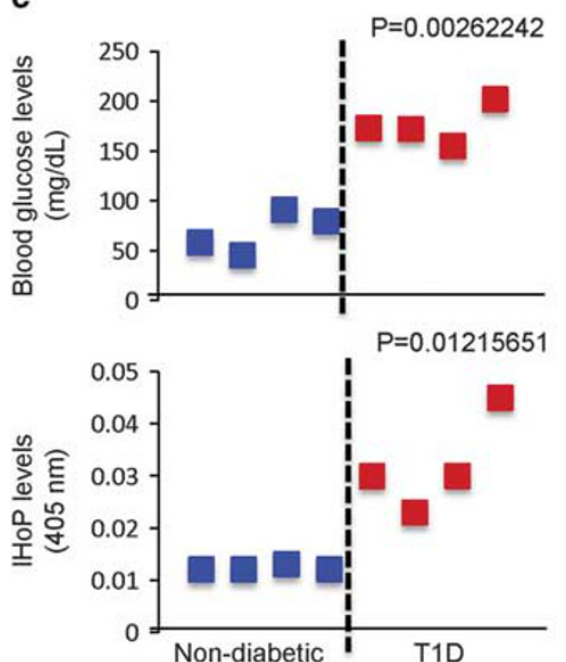

b
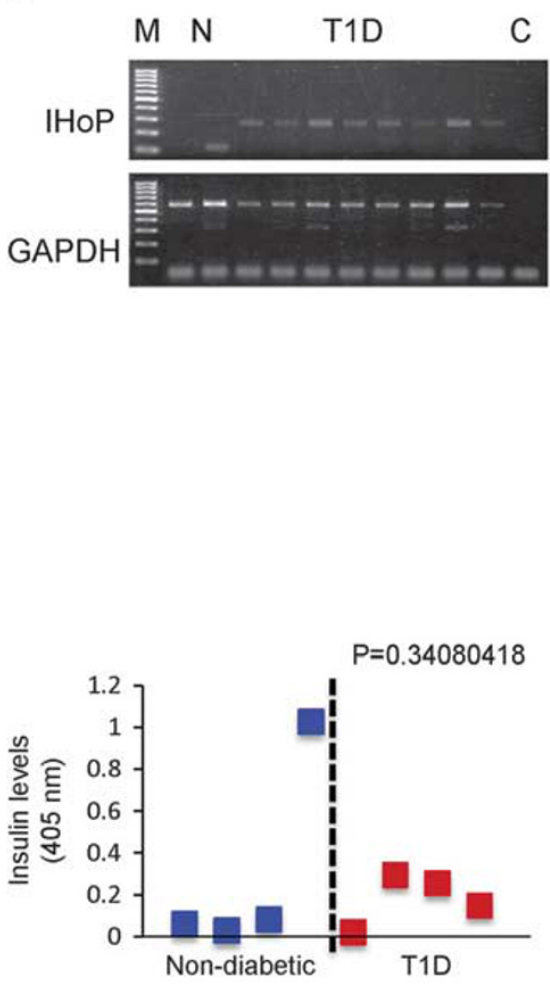

Figure $6 \mathrm{IHoP}$ as a biomarker for type 1 diabetes. (a) RT-PCR analysis for the IHoP and L-Plastin genes in aTC1.9 cells and type 1 diabetes pancreatic tissue. The primers used are listed in Table 1. White circles indicate IHoP mRNA presence, whereas the L-Plastin gene is not expressed. $\beta$-Actin (aTC1.9 cell) and GAPDH (human) as loading controls. M indicates $1 \mathrm{~kb}$ ladder. (b) Detection of IHoP in the serum of type 1 diabetes patients using RT-PCR N; nondiabetic human serum (Data shown represent two of four patients, all with same results), type 1 diabetes; serum from type 1 diabetes patients (patient population consisted of four males and four females with an age range of 5-50 years old, this cohort of samples were totally de-identified by NPOD and are used only as positive T1D samples), C; without RT. M indicates 100 bp ladder. (c) ELISA assays for insulin, glucose, and IHoP in human serum. Blue boxes represent nondiabetic samples, while the red figures show the diseased state. $n=4$.

stages of T1D. I. A T1D detection rate of $75 \%$ in known positive cases is the minimal accepted outcome. Even with the false-negative sample, our diagnosis level of our serum IHoP test gave us a $87.5 \%$ accuracy rate, which is far above the $75 \%$ level of clinically used autoantibody testing currently in use.

\section{DISCUSSION}

Presently, type 1 diabetes is viewed as an autoimmune disease culminating in the destruction of pancreatic $\beta$-cells and histologically characterized by islet cell inflammation. However, it remains unclear why this autoimmunity is exclusive to $\beta$-cells. ${ }^{16}$ Over the past several decades much has been learned, but the search continues for a causative agent that precipitates the cascade of events leading to diabetes. In the latest discussions on type 1 diabetes pathogenesis, mechanisms emphasizing a role for glucagon are being postulated. ${ }^{3,17}$

In this study, we investigated the expression of a novel protein called $\mathrm{IHoP}$, which is involved in the regulation of pancreatic islet function. By Genebank database blast, this protein shares close homology with L-Plastin (Supplementary Figure 1A), a protein expressed by certain hematopoietic cells (T cells), and malignant tumors. ${ }^{18,19}$ Mouse L-Plastin has 11 transcripts reported by the Ensemble database, with most of the differences located within the $5^{\prime}$ - and $3^{\prime}$-untranslated regions (UTRs), leading to an amino acid change from lysine (IHoP, AAA) to asparagine (L-Plastin, AAC). IHoP could prove to be yet another variant. We were able to confirm 
$\mathrm{IHoP}$ and L-Plastin to be distinctly separate proteins through immunohistochemistry on pancreatic tissue from L-Plastin knockout mice (Supplementary Figure 1C) and by double immunofluorescence staining on post-onset NOD mouse and human type 1 diabetes islets (Supplementary Figure 1B).

Under normal physiological conditions, glucagon secretion is maximal at low blood glucose levels, whereas higher glucose concentrations stimulate insulin release and reduce glucagon secretion. In a healthy pancreas, approximately $15-20 \%$ of the cells in an islet are glucagon-expressing $\alpha$-cells, ${ }^{20}$ however, it has been reported that in post-onset type 1 diabetes pancreatic islets, glucagon was expressed by the majority of islet cells. ${ }^{6}$ Using post-onset NOD mice and type 1 diabetes pancreatic tissues, our findings agree that the majority of cells in the diabetic islet are glucagon positive (Figure $1 \mathrm{~b}$ and c). In addition, dual immunofluorescence staining confirmed that IHoP localized with glucagon in the cytoplasmic compartment of $\alpha$-cells (Figure 1d). When IHoP-siRNA was transfected into $\alpha \mathrm{TC1} .9$ cells, no change in glucagon gene expression occurred as assessed by RT-PCR (data not shown). However, western blot analysis showed a dramatic decrease in glucagon protein expression (Figure 2f), indicating a translational function for IHoP.

To further define the phenomenon of alpha cell expansion within diabetic islets, we utilized a mouse $\alpha$-cell line. Figure $2 \mathrm{~d}$ shows that the addition of IHoP to cultured $\alpha$-cells had no significant effect on their proliferation. IHoP was not able to stimulate $\alpha$-cell proliferation and therefore not the reason for alpha cell expansion in the diseased islet. It seems that glucagon overexpression could be participating in the disease etiology.

Numerous theories have been propagated over the past few decades to describe the induction of $\beta$-cell autoimmunity including defective MHC II expression. What triggers the autoimmune response is not known, and perhaps such responses are not so much an attack on 'self' but a secondary reaction to an event causing antigen-presenting cells to become activated, thereby resulting in an activated immune (T-cell) response and the impression of autoimmunity. Normally, pancreatic endocrine cells do not express MHC class II molecules and weakly express MHC class I. ${ }^{21}$ Others have reported aberrant expression of MHC class II exclusively limited to islets with hyperexpression of MHC class I and approximately half of those islets had insulitis. ${ }^{22-24}$ Abnormal expression of MHC class II is associated with a minority of insulin-containing $\beta$-cells. ${ }^{24,25}$

In the NOD diabetic model we utilized, IHoP becomes overexpressed causing increased levels of glucagon, leading to a downregulation of insulin. At this point, $\beta$-cells enter an apoptotic phase causing a MHC class II immune response, which eventually elicits the characteristic T-cell response. It is this $\mathrm{T}$-cell response that results in the current dogma that diabetes is initiated by an autoimmune reaction.

In addition, our findings in Supplementary Figure 2 demonstrate that inhibition of the IHoP gene using an
IHoP-siRNA construct during the pre-onset period restricted dendritic cells from entering the islet as well as eliminated MHC class II expression. Perhaps blocking the $\beta$-cells from becoming apoptotic allowed the islet to maintain a homeostatic state and blocked the immune cell infiltration. The protection conferred by adoptive transfer with siRNA treated splenocytes was likewise associated with a lack of F4/80 and MHC class II expressions, explaining the ability of IHoP to hinder the immune response (Supplementary Figure 2). The most compelling aspect of this work was the discovery that injecting an IHoP suppressor during the pre-onset phase of diabetes successfully blocked the development of hyperglycemia for more than 35 weeks. This suggests that IHoP has a role in glucagon processing in the liver providing blood glucose level stability and also that it is involved in regulating liver glucose-6-phosphatase activity. Glucose-6-phosphatase contributes to blood glucose homeostasis by regulating both glycogen breakdown and conversion of glucose-6-phosphate into glucose, thereby increasing the glucose pool for hepatic output. ${ }^{26,27}$ Pre-onset IHoP-siRNA-treated NOD mouse liver had a decreased number of glucose-6-phosphatase-positive hepatocytes. These results indicated that IHoP impacted glucagon function in the liver, specifically through gluconeogenesis.

To further understand the mechanism of IHoP's role in altering the progression of disease in treated NOD mice, we analyzed the expression of Reg proteins and calcium binding proteins. Generally, Reg proteins are not expressed in the pancreatic $\beta$-cells, ${ }^{28}$ however, the Reg receptor is expressed by $\beta$-cells. ${ }^{29}$ Reg $3 \gamma,{ }^{28}$ a novel transcriptional target of Foxa2/ (HNF3 $\beta$ ) is a transcription factor known to stimulate PDX-1 to improve pancreatic growth and function..$^{30}$ Our current study shows that suppression of IHoP during early stages (pre-onset phase) of disease can activate Reg $3 \gamma$ expression leading to an increase in PDX-1 expression, which in turn will allow $\beta$-cell repair to occur and insulin production to resume (Figure 5). Not only were these factors upregulated compared with untreated post-onset NOD mice, there was an increase in the number and size of islets in treated versus untreated mice. These results suggest that the long-term normoglycemia maintained in pre-onset IHoP-siRNA-treated NOD mice was due to the ability of the pancreas to restore damaged islets to a normal functional level. ${ }^{31-33}$

To put this idea into perspective, we present a schematic (Figure 7) illustrating the proposed role $\mathrm{IHoP}$ has in type 1 diabetes progression. In the hyperglycemic state, $\alpha$-cells overproduce glucagon and $\mathrm{IHoP}$, whereas $\beta$-cells respond by downregulating insulin production. During this stage, a point of no return is approaching; the disease will either progress toward full onset or be diverted. Without intervention or treatment after this point of no return, the islet is destroyed leaving few, if any, $\beta$-cells and a massive immune response infiltrating the islet. This delineates full-onset disease where the amounts of both glucagon and IHoP being produced are extremely high. However, if suppression of 


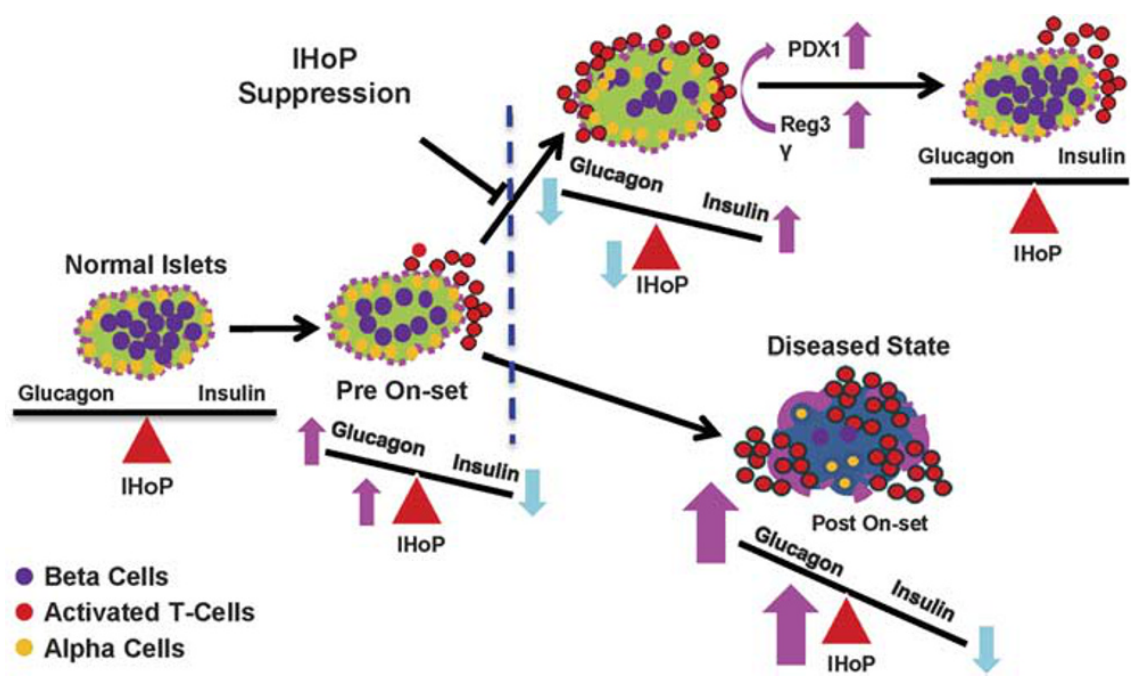

Figure 7 Schematic showing the proposed role that IHoP has in the progression of type 1 diabetes. Healthy pancreatic islets are in cellular and hormonal homeostasis. An increase in IHoP expression disrupts the balance within an islet causing glucose levels to increase resulting in pre-onset disease. Without intervention, levels of glucagon and IHoP continue to increase, and type 1 diabetes develops resulting in islet destruction (lower pathway). However, if $\mathrm{HOOP}$ is suppressed at the pre-onset stage, homeostasis is restored and the islet is able to regenerate through activation of the PDX-1 pathway by Reg-3y (upper pathway). The dashed blue line represents an arbitrary point in the progression of the disease, this point is something like a point of no return. Based on our data, we feel that if treatment is given before this point of no return the progression of the disease can be altered and the animals survive with normal glycemic levels, but if treatment is given after this point the disease progresses toward full onset of the T1D. Once the disease is considered full onset, the damage has been done and IHoP's role is insufficient to rescue the islet.

IHoP occurs during the pre-onset stage of the disease (before this point of no return), there is a decrease in both IHoP and glucagon expression, which in turn activates the islet repair/ restoration pathway via the Reg-3 $\gamma$-PDX-1 axis. This will eventually lead to homeostasis in the islet allowing a return to normal blood glucose levels.

This study verifies IHoP as a transcript localized within alpha cells, which can identify diabetic changes within pancreatic islets by merit of increased expression. Furthermore, the data presented within this report demonstrate that IHoP regulates glucagon secretion by $\alpha$-cells, but does not play a role in alpha cell expansion within the diabetic islet. In addition, the suppression of $\mathrm{IHoP}$ at an appropriate time during disease development can halt the progression of T1D and activate a healing response within the damaged islet. Our data also reveal that if treatment is given after this critical point nothing can be done to reverse the disease. Taken together, our data suggest that IHoP could be a novel target in the field of T1D research and that it appears to have a significant role in the progression of T1D. The presence of IHoP in the sera of newly diagnosed type 1 diabetes patients (not considered to be in full onset of the disease) alludes to its possible application as a potential new biomarker directly involved in T1D pathogenesis, which could contribute to improvements in T1D prediction/diagnosis. Finally, because we have shown that $\mathrm{IHoP}$ promotes restoration of islets through activation of the Reg- $3 \gamma$-PDX- 1 axis, application as a new potential therapeutic target for inhibiting the progression of T1D may be possible. In addition, the biomarker data provided (Supplementary Table 4) clearly shows that IHoP protein appears better in detecting early diagnosis. Our data also show that if IHoP treatment is given at a later time, the islet cannot be repaired nor can treatment ameliorate full onset of the disease. There is a point of no return within the progression of the disease and if treatment is given before this point, the progression can be stopped. Our data also show that when treatment is given in the early stages, the immune response is downregulated and the repair/regenerating pathway is activated. However, much more work needs to be done to fully understand both IHoP's role in T1D and the basic biology of this protein.

Supplementary Information accompanies the paper on the Laboratory Investigation website (http://www.laboratoryinvestigation.org)

\section{ACKNOWLEDGMENTS}

We thank Dr Sharon Celeste Morley from the Department of Pediatrics, Division of Infectious Diseases, Washington University school of Medicine for the generous gift of L-Plastin knockout mouse tissues. In addition, we thank Dr Clayton Mathews and his lab for scoring insulitis slides (Figure 4). We also thank Dr Mark Atkinson for his support as well as his thoughtful suggestions in experimental design and manuscript preparation. This work was supported in part by Children Miracle Network foundation from the Department of Pediatrics, College of Medicine, University of Florida, as well as with funds from the National Institute of Health grants DK60015 and DK58614 awarded to BEP.

\section{DISCLOSURE/CONFLICT OF INTEREST}

The authors declare no conflict of interest. 
1. Cryer PE. Hypoglycemia: still the limiting factor in the glycemic management of diabetes. Endocr Pract 2008;14:750-756.

2. Dunning BE, Gerich JE. The role of alpha-cell dysregulation in fasting and postprandial hyperglycemia in type 2 diabetes and therapeutic implications. Endocr Rev 2007;28:253-283.

3. Quesada I, Tuduri E, Ripoll C, et al. Physiology of the pancreatic alphacell and glucagon secretion: role in glucose homeostasis and diabetes. J Endocrinol 2008;199:5-19.

4. Bolli $G$, de Feo P, Compagnucci $P$, et al. Abnormal glucose counterregulation in insulin-dependent diabetes mellitus. Interaction of antiinsulin antibodies and impaired glucagon and epinephrine secretion. Diabetes 1983;32:134-141.

5. Gerich JE, Langlois M, Noacco $C$, et al. Lack of glucagon response to hypoglycemia in diabetes: evidence for an intrinsic pancreatic alpha cell defect. Science 1973;182:171-173.

6. Gepts W. Pathologic anatomy of the pancreas in juvenile diabetes mellitus. Diabetes 1965;14:619-633.

7. Foulis AK, Liddle CN, Farquharson MA, et al. The histopathology of the pancreas in type 1 (insulin-dependent) diabetes mellitus: a 25-year review of deaths in patients under 20 years of age in the United Kingdom. Diabetologia 1986;29:267-274.

8. Gepts W, De Mey J. Islet cell survival determined by morphology. An immunocytochemical study of the islets of Langerhans in juvenile diabetes mellitus. Diabetes 1978;27(Suppl 1):251-261.

9. Gromada J, Franklin I, Wollheim CB. Alpha-cells of the endocrine pancreas: 35 years of research but the enigma remains. Endocr Rev 2007;28:84-116.

10. Yu X, Park BH, Wang MY, et al. Making insulin-deficient type 1 diabetic rodents thrive without insulin. Proc Natl Acad Sci USA 2008;105: 14070-14075.

11. Oh SH, Darwiche $\mathrm{H}$, Cho JH, et al. Characterization of a novel functional protein in the pancreatic islet: islet homeostasis protein regulation of glucagon synthesis in alpha cells. Pancreas 2012;41:22-30.

12. Hamaguchi K, Leiter EH. Comparison of cytokine effects on mouse pancreatic alpha-cell and beta-cell lines. Viability, secretory function, and MHC antigen expression. Diabetes 1990;39:415-425.

13. Nuovo GJ. In situ PCR: protocols and applications. PCR Methods Appl 1995;4:S151-S167.

14. Christianson SW, Shultz LD, Leiter EH. Adoptive transfer of diabetes into immunodeficient NOD-scid/scid mice: relative contributions of CD4+ and CD8+ T lymphocytes from diabetic versus prediabetic NOD. NON-Thy-1a donors. Diabetes 1993;42:44-55.

15. Narushima $Y$, Unno $M$, Nakagawara $K$, et al. Structure, chromosoma localization and expression of mouse genes encoding type III Reg, Regllla, Reglll $\beta$, Regllly. Gene 1997;185:159-168.

16. Parker MJ, Xue S, Alexander JJ, et al. Immune depletion with cellular mobilization imparts immunoregulation and reverses autoimmune diabetes in nonobese diabetic mice. Diabetes 2009:58:2277-2284.

17. Atkinson MA, Bluestone JA, Eisenbarth GS, et al. How does type 1 diabetes develop?: the notion of homicide or beta-cell suicide revisited. Diabetes 2011;60:1370-1379.
18. Lee $\mathrm{Y}$, Wang $\mathrm{MY}, \mathrm{Du} \mathrm{X}$, et al. Glucagon receptor knockout prevents insulin-deficient type 1 diabetes in mice. Diabetes 2011;60: 391-397.

19. Lin CS, Chen ZP, Park T, et al. Characterization of the human L-plastin gene promoter in normal and neoplastic cells. J Biol Chem 1993;268: 2793-2801.

20. Park T, Chen ZP, Leavitt J. Activation of the leukocyte plastin gene occurs in most human cancer cells. Cancer Res 1994;54: 1775-1781.

21. Elayat $A A$, el-Naggar MM, Tahir M. An immunocytochemical and morphometric study of the rat pancreatic islets. J Anat 1995;186(Pt 3): 629-637.

22. Fernandez-Fernandez MR, Veprintsev DB, Fersht AR. Proteins of the S100 family regulate the oligomerization of p53 tumor suppressor Proc Natl Acad Sci USA 2005;102:4735-4740.

23. van Dieck J, Brandt T, Teufel DP, et al. Molecular basis of S100 proteins interacting with the p53 homologs p63 and p73. Oncogene 2010;29: 2024-2035.

24. Alejandro $R$, Shienvold FL, Hajek SV, et al. Immunocytochemical localization of HLA-DR in human islets of Langerhans. Diabetes 1982; 31(Suppl 4):17-22.

25. Pipelleers DG, in't Veld PA, Pipeleers-Marichal MA, et al. Presence of pancreatic hormones in islet cells with MHC-class II antigen expression. Diabetes 1987;36:8720876.

26. Foulis AK, Farquharson MA, Hardman R. Aberrant expression of class II major histocompatibility complex molecules by $B$ cells and hyperexpression of class I major histocompatibility complex molecules by insulin-containing islets in type I (insulin-dependent) diabetes mellitus. Diabetologia 1987;30:333-343.

27. Foulis AK, Farquharson MA. Aberrant expression of HLA-DR antigen by insulin-containing beta-cells in recent-onset type I diabetes mellitus. Diabetes 1986;35:1215-1224.

28. Imagawa $\mathrm{A}$, Hanafusa $\mathrm{T}$, Itoh $\mathrm{N}$, et al. Islet-infiltrating $\mathrm{t}$ lymphocytes in insulin-dependent diabetic patients express CD 80 (B7-1) and CD 86 (B7-2). J Autoimmun 1996;9:391-396.

29. Johnson LN, Barford D, Owen DJ, et al. From phosphorylase to phosphorylase kinase. Adv Second Messenger Phosphoprotein Res 1997;31:11-28.

30. Krebs EG. Phosphorylation and dephosphorylation of glycogen phosphorylase: a prototype for reversible covalent enzyme modification. Curr Top Cell Regul 1981;18:401-419.

31. Terazono $\mathrm{K}$, Uchiyama $\mathrm{Y}$, Ide $\mathrm{M}$, et al. Expression of reg protein in rat regenerating islets and its co-localization with insulin in the beta cell secretory granules. Diabetologia 1990;33:250-252.

32. Kobayashi S, Akiyama T, Nata K, et al. Identification of a receptor for reg (regenerating gene) protein, a pancreatic beta-cell regeneration factor. J Biol Chem 2000;275:10723-10726.

33. De Leon DD, Farzad C, Crutchlow MF, et al. Identification of transcriptional targets during pancreatic growth after partial pancreatectomy and exendin-4 treatment. Physiol Genomics 2006;24: 133-143. 